Sheridan College

SOURCE: Sheridan Institutional Repository

\title{
In Control of Life Chances? Visible Minority Immigrants and Sense of Mastery
}

Ferzana Chaze

York University, ferzana.chaze@sheridancollege.ca

Karen Robson

York University

Follow this and additional works at: https://source.sheridancollege.ca/fahcs_comm_publ

Part of the Social Work Commons

\section{SOURCE Citation}

Chaze, Ferzana and Robson, Karen, "In Control of Life Chances? Visible Minority Immigrants and Sense of Mastery" (2014). Faculty Publications and Scholarship. 9.

https://source.sheridancollege.ca/fahcs_comm_publ/9

\section{(c) (1) $(9)$}

This work is licensed under a Creative Commons Attribution-Noncommercial-No Derivative Works 4.0 License. This Article is brought to you for free and open access by the Publications and Scholarship at SOURCE: Sheridan Institutional Repository. It has been accepted for inclusion in Faculty Publications and Scholarship by an authorized administrator of SOURCE: Sheridan Institutional Repository. For more information, please contact source@sheridancollege.ca. 


\section{Research Note}

\section{In Control of Life Chances? Visible Minority Immigrants and Sense of Mastery}

\section{Introduction}

In the 1960s, Canada made many changes to its immigration policies, including the removal of restrictions based on applicant nationality (George, 2012). The result has been a shift in the demographic profile of immigrants in the past few decades. Traditionally, immigrants to Canada came from Europe. In recent years, this trend has been changing. According to the 2006 Canadian census, of the $6,186,950$ immigrants in Canada, 5,484,290 persons (88\%) came from Asia, the Middle East, Africa and Oceania (Statistics Canada, 2007). A majority of these immigrants belong to visible minority groups. Research has demonstrated that visible minority immigrants face many challenges in relation to their economic and social integration into Canadian society, which in turn negatively influences their health and wellbeing (FullerThomson, Novack \& George, 2011; Asanin Dean \& Wilson, 2009; Esete, \& Tachble, 2009; Kennedy \& McDonald, 2006).

The sense of control over life (also called mastery) experienced by immigrants in the face of the numerous settlement and integration challenges is an underdeveloped area of research. The ability to cope with life challenges, which is in turn related to a sense of control over one's life, has been acknowledged as a key determinant of health (Public Health Agency of Canada, 2003). A sense of mastery or control is thus an essential life skill for persons to be able to deal with everyday challenges and to pre-empt or avoid those that can be anticipated. In this study, we seek to understand whether being an immigrant, particularly a visible minority immigrant, predicts 
lower levels of sense of control over life chances. We compare the sense of mastery between immigrants and native-born Canadians using the 2008 General Social Survey (2008) data set. A unique contribution of this study is the nuanced understanding it provides about the vulnerability of visible minority immigrants in experiencing lower levels of mastery compared to other immigrants or non-immigrants. The findings would be of interest to practitioners working on issues of equity and diversity, immigration and mental health.

\section{Sense of Mastery and Visible Minority Immigrants}

Sense of mastery (hereafter "mastery") is understood to the perception of control that one has over his or her life chances (Milan, 2006; Pudrovska et al, 2005) and has been found to be positively associated with many life outcomes such as health and well-being in research with mixed ethnic groups (Milan; Wolinsky et al, 2003; Seeman \& Seeman, 1983) as well as minority groups (Jang, Kim, \& Chiriboga, 2006). Mastery has also been found to be a mediator in the effect of economic hardships during different life periods with mixed ethnic groups (Pudrovska et al) and a moderator between stress and burnout in a study that focussed on Israeli armed forces (Etzion \& Westman, 1994). While some studies have found age to be negatively associated with sense of control (Wolinsky et al; Jang, Kim, \& Chiriboga) findings from the General Social Survey-2003 (Milan) show a positive relationship between age and sense of mastery up to the age of 34 and a steady decline thereafter. The findings are contradictory in relation to gender and mastery. Gender has not been found to be associated with changes to sense of control in a study of older adults (Wolinsky et al), while in a study of Korean American immigrants (Jang, Kim, \& Chiriboga), females were found to have a lower sense of mastery. Other positive correlates of mastery include educational attainment (Milan; Wolinsky et al), income (Milan; 
Wolinsky et al) and being White (Wolinsky) or belonging to a majority group (Guinote, Brown \& Fiske, 2006).

The difficulties associated with migration and the subsequent processes of settlement have contributed to the conceptualization of migration as a social determinant of health (Davies, Basten \& Frattini, 2009). Though immigrants enter their host country healthy, their health tends to decline soon thereafter (Kennedy, McDonald \& Biddle, 2006; Gee, Kobayashi, Prus, 2004), and at higher rates than their native born counterparts in the host country. This is partly due to lower levels of social support and to the experiences of discrimination (Fuller-Thomson, Novack \& George, 2011). The physical, social, biological, cultural and psychological changes involved in the process of acculturation and its related stress (Krishnan \& Berry, 1992) have also been found to be related to negative health outcomes for immigrants (Finch \& Vega, 2003; Lee \& Yoon, 2011). Additionally, the challenges immigrants face in the process of settlement such as finding suitable employment, have been known to negatively affect various aspects of immigrants' lives and their physical, social, psychological or mental health (Asanin Dean \& Wilson, 2009; Esete, \& Tachble, 2009; Kennedy \& McDonald, 2006).

A large majority of immigrants to Canada enter the country under the "economic class", and often leave behind well-settled lives — secure employment, established professional practices/careers, large networks of friends and family — for the promise of a better future for their families in the host country. It should thus be logical to expect that such immigrants enter the country with a high sense of control over their lives and the direction in which they wish to chart it. Yet, past research has highlighted the lack of control perceived by immigrants (Milan, 2006; Jang, Kim, \& Chiriboga, 2006). It is likely that systemic barriers and difficulties immigrants face in finding suitable employment - such as lack of credential recognition 
(Becklumb \& Elgersma, 2008; Li, 2001), lack of Canadian work experience (Buzdugan \& Halli, 2009), language/accent discrimination (Creese \& Ngene Kambere, 2003; Munro, 2003) and racism (Li; Henry, \& Tator, 2006) — and their subsequent deskilling (Asanin Dean, \& Wilson, 2009) are possible contributors to immigrants' perceived lack of control over their life chances.

\section{Data and Methods}

We focus on mastery of visible minority immigrants in Canada based on an analysis of the Canadian General Social Survey 2008: Social Networks (GSS-22) public use microdata file (PUMF). Visible minorities are understood to be "persons, other than aboriginal peoples, who are non-Caucasian in race or non-white in colour" (Government of Canada, 1995, p.2). Based on the literature on acculturative stress and barriers to integration and its relationship with lower health outcomes, we hypothesized that immigrants, and visible minority immigrants in particular, are likely to have a lower sense of mastery compared to native born Canadians, even when controlling for key demographic characteristics. Specific research questions were:

- Is the sense of Mastery different for immigrants from that of native-born persons?

- Is the sense of Mastery of visible minority immigrants different from that of other immigrants and from that of native-born persons?

The GSS-22 is a quinquennial cross sectional survey that collects data from individuals 15 years and over in the ten provinces of Canada. The purpose of the GSS-22 study is to collect information in relation to the social networks and social and civic participation of Canadian residents. The sample was selected using random digital dialling method. It excludes households without telephones or which used only cellular phones. The survey instrument was administered 
by Statistics Canada via a telephone interview. The data for GSS Cycle 22 survey were collected between February and November, 2008. The non-response rate for GSS-22 was $42.7 \%$.

The outcome variable of interest for the analysis was sense of mastery, which was assessed with a scale created out of seven questions that assessed respondents' sense of control over events in their lives. As a goal of this study was to understand if and how sense of mastery is associated with processes of marginalisation that immigrants face, sense of mastery is treated as the dependent variable in this study. Participants were asked to either strongly agree, agree, neither agree nor disagree, disagree, or strongly disagree to each of the following statements: "You have little control over the things that happen to you," "There is really no way you can solve some of the problems you have," "There is little you can do to change many of the important things in your life," "You often feel helpless in dealing with problems of life," "Sometimes you feel that you are being pushed around in life," "What happens to you in the future mostly depends on you," and "You can do just about anything you really set your mind to." The mastery scale ranged from 0-28, with a higher score indicating higher mastery (Cronbach's alpha=0.75).

Independent variables of interest were whether the respondent was born outside Canada (1=yes) and whether or not one was a visible minority (1=no). Important demographic variables identified on the basis of the existing literature and controlled for were age (centered and grouped in five year bands), gender (female=1); highest level of education collapsed into five groups (doctorate/masters/bachelor's degree, diploma/certificate from community college, some university/community college, high school diploma, and some secondary/elementary/no schooling); total personal income in past 12 month from all sources (No income, less than $\$ 5,000, \$ 5,000$ to $\$ 9,999, \$ 10,000$ to $\$ 14,999, \$ 15,000$ to $\$ 19,999, \$ 20,000$ to $\$ 29,999, \$ 30,000$ 
to $\$ 39,999, \$ 40,000$ to $\$ 49,999, \$ 50,000$ to $\$ 59,999, \$ 60,000$ to $\$ 79,999, \$ 80,000$ to $\$ 99,999$, $\$ 100,000$ or more); sense of belonging to Canada (very strong, strong, somewhat weak, very weak, no opinion, don't know); self-rated physical health (excellent, very good, good, fair, poor.); and self-rated mental health (excellent, very good, good, fair and poor).

The working sample for this study consisted of the 19,293 persons who responded to the questions on the GSS-2008 related to mastery. Bivariate analyses were undertaken to determine the general associations between mastery and key independent variables. Multiple regression was carried out in three successive stages to determine the influence of key independent variables in predicting mastery. The analysis was conducted using STATA 12.

\section{Results}

Of foreign-born respondents, $11 \%$ were White and the remaining $89 \%$ were of visible minority status, while among Canadian-born respondents, $10 \%$ were of visible minority status. As can be seen in Table 1, a majority of the respondents were White (91\%), female (57\%), married (57\%), born in Canada (83\%) and had received earnings from income in the past year (59\%). A majority of respondents had strong or very strong sense of belonging to Canada (91\%), reported good, very good or excellent physical health (82\%), and good, very good or excellent mental health $(92 \%)$. 
Table 1: Characteristics of the Sample based on Key Variables (N=

\begin{tabular}{|l|l|}
\hline Ethnicity/Race & $\%$ \\
\hline White & 91.04 \\
\hline Visible Minority & 8.96 \\
\hline Gender & \\
\hline Male & 43.32 \\
\hline Female & 56.68 \\
\hline Education & \\
\hline Some secondary/elementary/no schooling & 20.31 \\
\hline High school diploma & 13.95 \\
\hline Some university/community college & 13.59 \\
\hline Diploma/certificate from community coll & 27.47 \\
\hline Doctorate/masters/bachelor's degree & $24.68)$ \\
\hline Marital Status & \\
\hline Married/Common law & 56.83 \\
\hline Previously Married & 20.81 \\
\hline Single & 22.36 \\
\hline Country of Birth & \\
\hline Canada & 82.82 \\
\hline Country outside Canada & 17.18 \\
\hline Whether received income from employment in past & \\
\hline 12 months & \\
\hline Yes & 58.95 \\
\hline No & 41.05 \\
\hline Sense of Belonging to Canada & \\
\hline Very weak & 2.63 \\
\hline Somewhat weak & 5.37 \\
\hline Somewhat strong | & 28.9 \\
\hline Very strong | & 62.34 \\
\hline Self Rated Health & 3.92 \\
\hline Poor & 13.40 \\
\hline Fair & 32.24 \\
\hline Good & 30.98 \\
\hline Very good & 19.46 \\
\hline Excellent & \\
\hline Self Rated Mental Health & 1.36 \\
\hline Poor & 7.11 \\
\hline Fair & 31.08 \\
\hline Good & 32.87 \\
\hline Very good & \\
\hline & \\
\hline
\end{tabular}


Table 2 reports the results of initial bivariate tests. Based on the literature we had hypothesized that there would be differences in the mastery scores of Whites/majority groups and visible minority persons (Guinote, Brown \& Fiske, 2006; Wolinsky et al, 2003); between the genders (Wolinsky et al; Jang, Kim, \& Chiriboga, 2006) and between groups with varied levels of levels of education and health (Milan, 2006; Wolinsky et al; Jang, Kim, \& Chiriboga). Significant differences were found in the mean mastery scores between Whites and visible minorities $(p<.001)$, males and females $(p<.01)$; those with some elementary or secondary scooping or no schooling and those with a high school diploma, some university/college education, diploma certificate holders from community colleges and those with a university degree $(p<.001)$, and among the married, previously married and single $(\mathrm{p}<.001)$. Statistically significant differences were also found between those born in Canada and in another country $(\mathrm{p}<.001)$; and among those who had received employment in the past 12 months and those who had not $(\mathrm{p}<.001)$; those with varying levels of physical health $(\mathrm{p}<.001)$; mental health $(\mathrm{p}<.001)$ and sense of belonging to Canada $(\mathrm{p}<.001)$. Based on the literature (Milan, 2006) we tested for a quadratic relationship between age and mastery and a significant quadratic relationship was found, which was included in the multivariate analyses. 
Table 2: Bivariate Analyses Comparing Mean Score of Key Independent variables with Sense of Mastery

\begin{tabular}{|c|c|c|c|}
\hline Variables & $\mathbf{N}$ & $\begin{array}{l}\text { Mean } \\
\text { Scores }\end{array}$ & \\
\hline $\begin{array}{l}\text { Ethnicity/Race } \\
\text { White }\end{array}$ & 18,218 & 19.23 & \multirow{2}{*}{$\begin{array}{l}\mathrm{t}=-12.1827 \\
\mathrm{p}<.001\end{array}$} \\
\hline Visible Minority & 1,792 & 18 & \\
\hline \multicolumn{4}{|l|}{ Gender } \\
\hline Male & 8,838 & 19.21 & \multirow{2}{*}{$\begin{array}{l}t=3.0303 \\
p<.01\end{array}$} \\
\hline Female & 11,563 & 19.04 & \\
\hline \multicolumn{4}{|l|}{ Country of Birth } \\
\hline Canada & 16,637 & 19.27 & \multirow{2}{*}{$\begin{array}{l}\mathrm{t}=12.1524 \\
\mathrm{p}<.001\end{array}$} \\
\hline Country outside Canada & 3,452 & 18.35 & \\
\hline \multicolumn{4}{|c|}{ Sense of Belonging to Canada } \\
\hline Very weak & 522 & 18 & \multirow{4}{*}{$\begin{array}{l}\mathrm{F}=25.72 \\
\mathrm{p}<.001\end{array}$} \\
\hline Somewhat weak & 1,073 & 19 & \\
\hline Somewhat strong & 5,790 & 19 & \\
\hline Very strong & 12,459 & 19 & \\
\hline
\end{tabular}

Mean Score ${ }^{1: \text { Scored from 0-28 }}$

Three linear multivariate ordinary least squares regression models were created to explore the unique effects of visible minority status and immigrant status on mastery. Variables were added in three blocks in order to examine the effect of immigrant and visible minority status on mastery. As can be seen in Table 3, in the first model only the primary variables of interest -visible minority status and immigrant status -- were included as predictors. While statistically significant and in the expected directions, as the sole independent variables these factors resulted in poor model fit $\left(\mathrm{R}^{2}=0.01\right)$, In Model 2 other known determinants of mastery as guided by the literature were added and the model fit was substantially improved $\left(\mathrm{R}^{2=} 0.24\right)$. The addition of these control variables prevents us from overstating the relationship between immigrant and 
visible minority status and mastery by accounting for the effects of other known determinants.

Table 3: Multivariate Regression Predicting Mastery

\begin{tabular}{|c|c|c|c|}
\hline & Model 1 & Model 2 & Model 3 \\
\hline Visible Minority $(1=$ no $)$ & $0.806^{* * *}$ & $1.304^{* * *}$ & $0.525^{*}$ \\
\hline Born outside Canada (1=yes) & $-0.590^{* * *}$ & $-0.422^{* * *}$ & $-1.268^{* * *}$ \\
\hline \multicolumn{4}{|l|}{ Education } \\
\hline High school diploma & & $0.546^{* * *}$ & $0.550^{* * *}$ \\
\hline $\begin{array}{l}\text { Some university/community } \\
\text { college }\end{array}$ & & $1.139^{* * *}$ & $1.130^{* * * *}$ \\
\hline $\begin{array}{l}\text { Diploma/certificate from } \\
\text { community college }\end{array}$ & & $0.995^{* * *}$ & $0.996^{* * *}$ \\
\hline $\begin{array}{l}\text { Doctorate/masters/bachelor's } \\
\text { degree }\end{array}$ & & $1.487^{* * *}$ & $1.272^{* * *}$ \\
\hline Female $(1=$ yes $)$ & & $0.294^{* * *}$ & $0.291^{* * *}$ \\
\hline \multicolumn{4}{|l|}{$\begin{array}{l}\text { Marital Status } \\
\text { (Ref: Married/Common Law) }\end{array}$} \\
\hline Previously Married & & -0.119 & -0.122 \\
\hline Single & & $-0.210^{* *}$ & $-0.224^{* *}$ \\
\hline Centered Age & & $-0.226^{* * *}$ & $-0.226^{* * *}$ \\
\hline Centered Age2 & & $0.00865^{* * * *}$ & $0.00765^{* *}$ \\
\hline Income & & $0.187^{* * *}$ & $0.185^{* * *}$ \\
\hline Self-Rated Health & & $0.517^{* * *}$ & $0.517^{* * *}$ \\
\hline Self-Rated Mental Health & & $0.951^{* * *}$ & $0.952^{* * *}$ \\
\hline Sense of Belonging to Canada & & $0.404^{* * *}$ & $0.403^{* * *}$ \\
\hline $\begin{array}{l}\text { Place of Birth X Visible } \\
\text { Minority Status } \\
\end{array}$ & & & $1.090^{* * *}$ \\
\hline _cons & $18.49^{* * *}$ & $8.772^{* * * *}$ & $9.559^{* * *}$ \\
\hline $\mathbf{R 2}$ & 0.99 & 24.16 & 24.26 \\
\hline$N$ & 19122 & 15616 & 15616 \\
\hline
\end{tabular}

As can be seen in Model 2, the effect of the visible minority status increased $(b=1.304)$, as being phenotypically part of the majority was significantly and strongly associated with mastery. Being born outside Canada was negatively associated with mastery, and this effect weakened somewhat between Models 1 and 2, suggesting that some of that effect is mediated by the controls used in 
Model 2. In terms of the controls examined in the model, they all exhibited the expected effects as suggested in the previous literature. Level of education was positively associated with mastery, as was being female. Age (centered) was shown to have a curvilinear association with mastery, while marital statuses other than being partnered were negatively associated with the outcome variable. Income, self-related health, and sense of belonging in Canada were also positively associated with mastery.

In the third Model, we added an exploratory interaction term to test if the effect of visible minority status on mastery was differentially impacted by whether or not a person was born in Canada. This interaction relationship was found to be statistically significant $(p<.001)$. Being born outside of Canada lowered the scores on the Mastery scale for both Whites and visible minorities, however penalty of being a visible minority and an immigrant were much higher.

\section{Discussion}

While an earlier cycle of the GSS (Milan, 2006) had identified that immigrants in Canada experience a lower sense of mastery than native born persons, a key contribution of this study is a nuanced understanding of the manner in which mastery is differentially experienced by immigrants. The findings of this study point to the vulnerability of all immigrants in the process of settling and integrating into the host country in terms of their psycho-social health. Being a racialized immigrant predicted the lowest scores on the mastery scale compared to other immigrants and non-immigrants, pointing to the unique disadvantages faced by these immigrants at the "intersections" (Baca Zinn \& Thornton Dill, 1996; Fellows \& Razack, 1998; Hill Collins, 2000) of race and outsider status that are not experienced by persons who are either only immigrant or Canadian-born visible minorities. 
Having a strong sense of belonging to Canada was found to be an important predictor of mastery. Previous research has shown that length of time in the country may also play a role in the sense of belonging and identification as Canadian citizens (Gilkinson \& Sauvé, 2010). ${ }^{1}$ Possible reasons are that it takes to form meaningful connections in a new country and also that new immigrants are not allowed to apply for legal citizenship in the initial years (Gilkinson \& Sauvé). It is also likely that immigrants who are dissatisfied with life in Canada on account of not being able to find work (George et al, 2012) and who might even be considering return or onward migration (Ho, 2010) might not develop this strong feeling of belonging, which in turn has implications on their sense of mastery and capacity to cope with life's challenges.

Consistent with the literature (Milan; Wolinsky et al, 2003; Jang, Kim, \& Chiriboga, 2006; Seeman \& Seeman, 1983) our study confirms a relationship between sense of mastery and physical and mental health. Similar to Lee \& Yoon (2011) we propose that lowered physical and mental health on account of acculturative stress can contribute to lower mastery for immigrants. Future research could explore the complex relationship between immigrants' sense of mastery and their physical and mental health. Longitudinal research could correctly capture the changes in the sense of mastery over time.

The limitations of this study are the cross sectional nature of the Canadian General Social Survey data study and the underrepresentation of persons from very low income groups due to the telephone survey method of data collection. This might lead to a bias in the results as they are dependent on the sample from which the data has been collected. Another limitation is that the variable used to study the immigrant population did not differentiate between immigrants and refugees. Unlike immigrants, refugees might have migrated under a great deal of stress and

\footnotetext{
${ }^{1}$ While theoretically interesting, it was not possible to statistically test this assumption due to the high collinearility of "time in Canada" with the age of the majority of respondents, who were Canadian-born.
} 
duress, and without much planning and might continue to face many continuing challenges emerging out of their migration experiences (Segal, 2002), all of which might negatively impact their sense of control. Though refugees make up a small portion (approximately 11\%) of the total migrant population entering the country in the past few years (CIC, 2012) it is likely that the inclusion of this population could have impacted the mastery scores of the immigrant group. This paper has highlighted the manner in which immigration influences mastery. It underlines the vulnerability of immigrants and visible minority immigrants in particular in experiencing lower levels of control over their lives. It joins other studies in urging the need for urgent action on the systemic barriers impacting immigrants' integration into Canadian society. Future research can compares findings in relation to visible minority immigrants and sense of mastery in major Canadian gateway cities with a high concentration of visible minority immigrants. Such comparison can also be made in relation data on visible minority immigrants from other countries. It would also be interesting to understand whether sense of mastery differs for different visible minority groups based on linguistic or other cultural differences such as religion.

\section{References}

Asanin Dean, J. \& Wilson, J. (2009). "Education? It is irrelevant to my job now and it makes me very depressed": Exploring the health impacts of under/unemployment among highlyskilled recent immigrants in Canada. Ethnicity \& Health, 14(2), 185-204.

DOI: $10.1080 / 13557850802227049$

Baca Zinn, M., \& Thornton Dill, B. (1996). Theorizing Difference from Multiracial Feminism. Feminist Studies, 22(2), 321-331. 
Becklumb, P., \& Elgersma, S. (2008). Recognition of the Foreign Credentials of Immigrants. $\begin{array}{llll}\text { Parliament } & \text { of } & \text { Canada. } & \text { Retrieved }\end{array}$ http://www.parl.gc.ca/Content/LOP/researchpublications/prb0429-e.htm\#measuring

Buzdugan, R., \& Halli, S. S. (2009). Labor Market Experiences of Canadian Immigrants with Focus on Foreign Education and Experience. International Migration Review, 43(2), $366-386$.

Citizenship and Immigration Canada (CIC) (2012). Facts and figures 2011 - Immigration overview: Permanent and temporary residents. Retrieved from http://www.cic.gc.ca/english/resources/statistics/facts2011/permanent/02.asp

Creese, G., \& Ngene Kambere, E. (2003). What Colour is your English. The Canadian Review of Sociology and Anthropology, 40, 565-573.

Davies, A. A., Basten, A., \& Frattini, C. (2009). Migration: A Social - of the Health of Migrants. International Organization for Migration. Retrieved on July 30, 2010 from http://www.migrant-healtheurope.org/files/Migration\%20a\%20Determinant\%20of\%20Health_Background\%20Pape r(1).pdf

Esete, D. C., \& Tachble (2009). The Perceptions and Experiences of Russian Immigrant and Sudaneese Refugee Men as Fathers in an Urban Centre in Canada. ANNALS, AAPSS, 624, 139-153. doi: $10.1177 / 0002716209334470$

Etzion, D. \& Westman, M. (1994). Social Support and Sense of Control as Moderators of the Stress-Burnout Relationship in Military Careers. Journal of Social Behavior and Personality, 9(4), 639-656. 
Fellows, M. L., \& Razack, S. (1998). The Race to Innocence: Confronting hierarchical relations among women. The Journal of Gender, Race and Justice, 1, 335-352

Finch, B. K. \& Vega, W.A. (2003). Acculturation stress, social support, and self-rated health among Latinos in California. Journal of Immigrant and Minority Health, 5(3), 109-117.

Fuller-Thomson, E., Novack, A., \& George, U. (2011) Health Decline among Recent Immigrants to Canada: Findings from a Nationally-representative Longitudinal Survey. Canadian Journal of Public Health. 102(4), 273-80.

Gee, E., Kobayashi, K., Prus, S.G. (2004). Examining the healthy immigrant effect in mid-tolater life: Findings from the Canadian Community Health Survey. Canadian Journal of Aging, 23(Supplement):S61-S69.

George, U. ( 2012) Immigration and refugee policy in Canada: Past, present and future. In A. Westhues (Ed.), Canadian Social Policy (5th edition). (pp 333-354). Waterloo: Wilfrid Laurier Press

George, U., Chaze, F., Fuller-Thomson, E., \& Brennenstuhl, S. (2012). Underemployment and Life Satisfaction: A study of internationally-trained engineers in Canada. Submitted to the Journal of Immigration and Refugee Studies.

Gilkinson, T., \& Sauvé, G. (2010). Recent immigrants, earlier immigrants and the Canadianborn: Association with collective identities. Research and Evaluation. Citizenship and $\begin{array}{llll}\text { Immigration } & \text { Canada. } & \text { Retrieved } & \text { from }\end{array}$ http://www.cic.gc.ca/english/resources/research/2011-collectid/index.asp

Government of Canada. (1995). Employment Equity Act. Retrieved from http://lawslois.justice.gc.ca/PDF/E-5.401.pdf 
Guinote, A., Brown, M., \& Fiske, S.T. (2006). Minority status decreases sense of control and increases interpretive processing. Social Cognition, 24, 169-186. doi: $10.1521 /$ soco.2006.24.2.169

Lee, K. H., \& Yoon, D. P. (2011). Factors influencing the general well-being of low-income Korean immigrant elders. Social Work, 56 (3), 269-279.

Henry, F., \& Tator, C. (2006). The colour of democracy: Racism in Canadian society. Toronto: Thomson Canada.

Hill Collins, P. (2000). Black Feminist Thought: Knowledge, consciousness, and the politics of empowerment (2nd ed. ed.). New York: Routledge.

Ho, E. (2010). Caught between Two Worlds: Mainland Chinese Return Migration, Hukou Considerations, and the Citizenship Dilemma. Metropolis British Columbia Working $\begin{array}{llll}\text { Paper } & \text { Series. } & \text { Retrieved } & \text { from }\end{array}$ http://riim.metropolis.net/assets/uploads/files/wp/2010/WP10-06.pdf

Jang, Y., Kim, G., \& Chiriboga, D. A. (2006). Correlates of sense of control among older Korean American older immigrants: Financial status, physical health constraints, and environmental challenges. International Journal of Aging and Human Development, 63(3), 173-186.

Kennedy, S., McDonald J.T., \& Biddle, N (2006). The healthy immigrant effect and immigrant selection: Evidence from four countries. Retrieved from http://www1.carleton.ca/sppa/ccms/wp-content/ccms-files/chesg-mcdonald.pdf

Kennedy, S., \& McDonald, J. T. (2006). Immigrant Mental Health and Unemployment. The Economic Record, 82 (259). 445-459. 
Krishnan, A., \& Berry, J. W. (1992). Acculturative stress and acculturative attitudes among Indian immigrants to the United States. Psychology and Developing Societies, 4(2), 187212.

Li, P.S. (2001). The Market Worth of Immigrants' Educational Credentials, Canadian Public Policy/Analyse de Politiques, 27(1):23-38.

Milan, A. (2006). Taking Charge: Perceptions of Control over Life Chances. Canadian Social Trends. Statistics Canada. Catalogue No. 11-008.

Munro, M.J. (2003). A Primer on Accent Discrimination in the Canadian Context. TESL Canada Journal, 20 (2), 38-51.

Public Health Agency of Canada (2003). What Makes Canadians Healthy or Unhealthy? http://www.phac-aspc.gc.ca/ph-sp/determinants/determinants-eng.php

Pudrovska T, Schieman S, Pearlin LI, Nguyen K. (2005). The sense of mastery as a mediator and moderator in the association between economic hardship and health in late life. Journal of Aging and Health, 17(5), 634-60.

Seeman, M., \& Seeman, T. (1983). Health Behavior and Personal Autonomy: A Longitudinal Study of the Sense of Control in Illness. Journal of Health and Social Behavior. 24 (2), 144.

Segal, U. (2002). Framework for Immigration: Asians in the United States. New York: Columbia University Press.

Statistics Canada. (2007). Immigrant population by place of birth, by province and territory (2006 Census). Retrieved from http://www.statcan.gc.ca/tables-tableaux/sumsom/101/cst01/demo34a-eng.htm

Wolinsky, F. D., Wyrwich, K. W., Babu, A. N., Kroenke, K., Tierney, W. M. (2003). Age, aging, and the sense of control among older adults: a longitudinal reconsideration. 
Journal of Gerontology: Social Sciences, 58B, S212-S220. doi: 10.1093/geronb/58.4.S212 